\title{
Dairy cow excreta patches change the boreal grass swards from sink to source of methane
}

\author{
Marja Maljanen ${ }^{1 *}$, Perttu Virkajärvi ${ }^{2}$ and Pertti J. Martikainen ${ }^{1}$ \\ ${ }^{1}$ University of Eastern Finland, Faculty of Science and Forestry, Department of Environmental Science, P.O. Box 1627, \\ FI-70211 Kuopio, Finland
}

${ }^{2}$ MTT Agrifood Research Finland, Animal Production Research, Halolantie 31 A, Fl-71750 Maaninka, Finland e-mail: marja.maljanen@uef.fi

\begin{abstract}
We studied the annual methane $\left(\mathrm{CH}_{4}\right)$ flux rates from experimental excreta patches on a boreal dairy pasture in Eastern Finland. The $\mathrm{CH}_{4}$ fluxes were measured with a chamber technique during snow free seasons and with gas gradient technique during winter from timothy-meadow fescue sward with mineral $\mathrm{N}$ fertilization $\left(220 \mathrm{~kg} \mathrm{ha}^{-1}\right)$ and from grass-white clover mixture without mineral $\mathrm{N}$ addition. The simulated dung and urine patches were applied in June or August two consecutive grazing seasons. The measurements were carried out for a year following each application except for the last application period, measurements were extended to two years. There were no significant differences in $\mathrm{CH}_{4}$ fluxes between plant species. $\mathrm{CH}_{4}$ emissions originated mainly from the fresh dung pats. The annual $\mathrm{CH}_{4}$ fluxes from the control sites without excreta were on average $-0.60 \pm 0.1 \mathrm{~kg} \mathrm{CH}_{4} \mathrm{ha}^{-1}$ (net uptake) and with the excreta $0.47 \pm 0.3 \mathrm{~kg}$ $\mathrm{CH}_{4} \mathrm{ha}^{-1}$ (net emission). Thus, excreta originating from dairy cows can turn boreal swards from weak sinks to small sources of $\mathrm{CH}_{4}$. However, these $\mathrm{CH}_{4}$ emissions from pasture are only $0.2 \%$ of the total $\mathrm{CH}_{4}$ emissions from a dairy cow.
\end{abstract}

Key words: methane, emission, dung, urine, agriculture, grazing

\section{Introduction}

Methane $\left(\mathrm{CH}_{4}\right)$ is a strong greenhouse gas and it has a warming potential 25 times that of $\mathrm{CO}_{2}$ in a 100-year reference period (Solomon et al. 2007). Concentration of $\mathrm{CH}_{4}$ in the atmosphere has more than doubled since pre-industrial time (Solomon et al. 2007). The most important sources of methane include wetlands, rice paddies, waste and manure treatment, biomass burning, coal mining and enteric fermentation in the ruminants (Hütsch 2001). The most important terrestrial sinks for $\mathrm{CH}_{4}$ are forest soils, whereas well aerated, drained agricultural soils are only weak net sinks (Hütsch 2001). In these soils methanotrophic bacteria oxidize atmospheric methane diffused in the soil causing the $\mathrm{CH}_{4}$ sink (Hütsch 2001). However, if these soils are used as dairy pastures, the $\mathrm{CH}_{4}$ produced in the enteric fermentation by ruminants (Rossi et al. 2001) and in dung may result in net $\mathrm{CH}_{4}$ emissions from the site (emissions exceed uptake by soil). Furthermore, $\mathrm{CH}_{4}$ oxidation in pasture soil can be inhibited by high concentration of ammonium in urine (Mosier et al. 1991, Hütsch 2001, Xu and Inubushi 2004) thereby decreasing the $\mathrm{CH}_{4}$ uptake. Methane fluxes from boreal pasture soils have not been reported earlier. 


\section{AGRICULTURAL AND FOOD SCIENCE}

M. Maljanen et al. (2012) 21: 91-99

Well drained grass swards on boreal sandy soils have been identified as weak sinks for atmospheric methane (e.g. Syväsalo et al. 2006, Regina et al. 2007), but emissions from animal excreta during the short grazing season and the following winter are not known. Our hypothesis is that the dairy cow excreta (urine and dung) will change the conditions in grass sward ecosystem and increase the risk for $\mathrm{CH}_{4}$ emissions. To test this hypothesis we investigated the effect of dairy cow excreta on $\mathrm{CH}_{4}$ fluxes from a boreal pasture soil using simulated dung and urine patches.

\section{Materials and Methods}

\section{Study site}

The study site is located in eastern Finland $\left(63^{\circ} 09^{\prime} \mathrm{N}, 27^{\circ} 20^{\prime} \mathrm{E}\right)$ which is important dairy production area in Finland. The length of the grazing season in this area is an average 110 days from early June to middle of September. The soil type according to FAO classification is medium textured (clay and silt $20.4 \%$, finer sand $70.4 \%$, coarse sand 9.2\%) Dystric Regosol. The content of total $\mathrm{N}$ is $0.12 \%$, total P $1.73 \%$, the organic matter content is $5.7 \%$ and soil $\mathrm{pH}_{(\mathrm{H} 2 \mathrm{O})} 6.0$. Water table level remained deeper than $5 \mathrm{~m}$ during the study years (Saarijärvi et al. 2007). Mean annual temperature (1971-2000) in the region is $2.8^{\circ} \mathrm{C}$ and mean annual precipitation $609 \mathrm{~mm}$, of which approximately $50 \%$ falls as snow. The grass (mixture of Phleum pratense L. and Festuca pratensis Huds.) and grass-clover (mixture of Trifolium repens, Trifolium hybridium and Poa pratensis) swards were established in spring 2000. Grass sward, including the excreta plots, was fertilized at an annual rate of $220 \mathrm{~kg} \mathrm{ha}^{-1} \mathrm{~N}_{\text {as }} \mathrm{NH}_{4} \mathrm{NO}_{3}$ whereas grass-clover sward remained unfertilized.

On 10 June 2002, in the beginning of the grazing season, six urine $\left(2.37 \mathrm{~kg} \mathrm{plot}^{-1}\right.$, equals to $59 \mathrm{~g} \mathrm{~N} \mathrm{~m}^{-2}$, size $0.36 \mathrm{~m}^{2}$ ) and six dung (2.47 $\mathrm{kg} \mathrm{plot}^{-1}$, equals to $113 \mathrm{~g} \mathrm{~N} \mathrm{~m}^{-2}$, size $0.075 \mathrm{~m}^{2}$ ) plots (referred to as urine I or dung I) were established on a grass sward. These were measured average amounts of excreta from dairy cows at that farm. Dung and urine were collected directly from cows less than $1 \mathrm{~h}$ before application. Six control plots (with mineral fertilizer) were also chosen from the grass sward. There was one collar for gas flux measurements on each plot and the applications of dung or urine were made directly inside the collars. Urine covered the whole collar area $\left(0.36 \mathrm{~m}^{2}\right)$, which was the average area for urine patches measured from the field. Dung patch covered $0.08 \mathrm{~m}^{2}$, similarly. On 26 August 2002, in the late grazing season, new six patches (referred to as urine II or dung II) were established to different locations similarly. During the next growing season new six patches again to different locations were applied on 10 June 2003 (urine III and dung III) and on 26 August 2003 (urine IV and dung IV) on grass sward (three replicates) and on grass-clover sward (three replicates). During the growing season, the plants from the experimental plots were cut 5 times to simulate the normal grazing cycle. The gas flux measurements of dung IV and urine IV patches continued until early June 2005. Period from June 2004 to June 2005 is referred here as "after effect year" and no new patches were applied during that period.

\section{Gas flux measurements}

The $\mathrm{CH}_{4}$ flux rates were measured weekly or biweekly with a static chamber method $(60 \times 60 \mathrm{~cm}, \mathrm{~h} 30$ $\mathrm{cm})$ and collars $(60 \times 60 \mathrm{~cm}$, h $15 \mathrm{~cm}$ ) pre-installed in the soil (Virkajärvi et al. 2010). Chambers were sampled with a polypropylene syringe at 5, 10, 15 and $25 \mathrm{~min}$ after closure and gas concentrations were analysed within 24 hours from sampling with a gas chromatograph (Shimadzu GC-14B, Shimadzu corp. JAPAN) equipped with flame ionization (FI) detector (Maljanen et al. 2003). Compressed air containing $1.98 \mathrm{I} \mathrm{I}^{-1} \mathrm{CH}_{4}$ was used for hourly calibration and the gas fluxes were calculated from the linear increase 


\section{AGRICULTURAL AND FOOD SCIENCE}

M. Maljanen et al. (2012) 21: 91-99

or decrease of the gas concentrations in the headspace of the chamber. Flux rates close to zero were not eliminated. During growing season the volumetric soil moisture was determined using Theta Probe (type ML2, Delta-T-Devices, UK) and soil temperature at depth $5 \mathrm{~cm}$ using a YC-260 thermometer (YCT, Taiwan) during each measurement from the control plots. Together with gas fluxes the $\mathrm{CH}_{4}$ concentration in soil air was measured using silicone tube gas collectors installed at depth of $5 \mathrm{~cm}$ in grass sward before application of IV urine and IV dung patches (details in Virkajärvi et al. 2010).

Chamber method cannot be used in the winter with snow cover and below $0{ }^{\circ} \mathrm{C}$ temperatures. Therefore, the gas flux rates from the snow-covered soil were determined by measuring the gas concentration gradients in snow pack and by calculating associated diffusion rates in the snow (Sommerfeld et al. 1993). Gas samples $(40 \mathrm{ml}$ ) from the snow pack directly over the dung or urine application or from control plots were drawn with a stainless steel probe $(\varnothing 3 \mathrm{~mm}$, length $50 \mathrm{~cm}$ ) (details in Virkajärvi et al. 2010).

In addition to field measurements, a bucket experiment was carried out in autumn 2002. Dung and urine (amounts as described above) were placed in a closed plastic buckets (three dung and three urine replicates) to measure the direct emission from the urine or dung, without soil, at the time of application. $\mathrm{The}_{4} \mathrm{CH}_{4}$ flux measurements from the buckets were made $0.5 \mathrm{~h}$ and $72 \mathrm{~h}$ after application and samples were taken and analyzed as described above.

\section{Results}

Control plots (pasture soil without excreta) were weak sinks for methane (mean $-0.39 \mathrm{mg} \mathrm{CH}_{4} \mathrm{~m}^{-2} \mathrm{~d}^{-1}$, range from -2.45 to $\left.1.11 \mathrm{mg} \mathrm{CH}_{4} \mathrm{~m}^{-2} \mathrm{~d}^{-1}\right)$. $\mathrm{CH}_{4}$ uptake increased with increasing air $(p<0.001, \mathrm{R}=0.396$ Pearson correlation) and soil temperatures ( $p<0.001, \mathrm{R}=0.257$ Pearson correlation) and decreased with increasing soil moisture ( $p<0.001, \mathrm{R}=0.401$, Pearson correlation). Thus, $\mathrm{CH}_{4}$ uptake occurred mainly during the growing season but weak uptake was detected also during the winter. There were no significant emission/ uptake peaks during the study period. During one day with extremely high precipitation $(87 \mathrm{~mm})$ a weak $\mathrm{CH}_{4}$ emission peak was measured on control grass plots.

In urine plots the $\mathrm{CH}_{4}$ emissions peaked (up to $15 \mathrm{mg} \mathrm{CH}_{4} \mathrm{~m}^{-2} \mathrm{~d}^{-1}$ ) immediately after application of urine but only during the first growing season (patches I and II, Fig. 1). However, dung emitted high amounts of $\mathrm{CH}_{4}$ (> $200 \mathrm{mg} \mathrm{CH}_{4} \mathrm{~m}^{-2} \mathrm{~d}^{-1}$ ) immediately after application on soil in all plots. This high emission peak from dung was short-lived (Fig. 1), and the dung plots acted again as a weak $\mathrm{CH}_{4}$ sink about two weeks after application. One year after the dung application (after effect year), the $\mathrm{CH}_{4}$ uptake rates from soil treated with dung were close to those in control plots and the dung was hardly recognizable on the soil. In the bucket experiment urine alone emitted small amounts of $\mathrm{CH}_{4}$ for the first $0.5 \mathrm{~h}$ after application $\left(0.11 \mathrm{mg} \mathrm{kg}^{-1} \mathrm{~d}^{-1}\right)$ and emission were not detectable after $72 \mathrm{~h}$. In comparison, dung emitted $\mathrm{CH}_{4}$ at a rate of $11.9 \mathrm{mg} \mathrm{kg}^{-1} \mathrm{~d}^{-1}$ for the first $0.5 \mathrm{~h}$ after application and was still emitting $2.2 \mathrm{mg} \mathrm{kg}^{-1} \mathrm{~d}^{-1}$ after $72 \mathrm{~h}$. Soil $\mathrm{CH}_{4}$ concentration at depth of $5 \mathrm{~cm}$ in control and urine plots remained close to the ambient level during the growing season, but $\mathrm{CH}_{4}$ concentration in soil was lower than that in ambient air during the winter (Fig. 2). However, under the dung plots a high concentration (mean $15 \mathrm{\mu l} \mathrm{I}^{-1}$ ) of $\mathrm{CH}_{4}$ was detected from the soil air a week after application, but two weeks later the concentration was close to ambient level $\left(1.8 \mu \mathrm{l} \mathrm{I}^{-1}\right)$. A slight increase in $\mathrm{CH}_{4}$ concentration was seen during soil thawing in May 2004 but not in 2005. There were no significant differences between the treatments during the "after effect" year. 


\section{AGRICULTURAL AND FOOD SCIENCE}

M. Maljanen et al. (2012) 21: 91-99

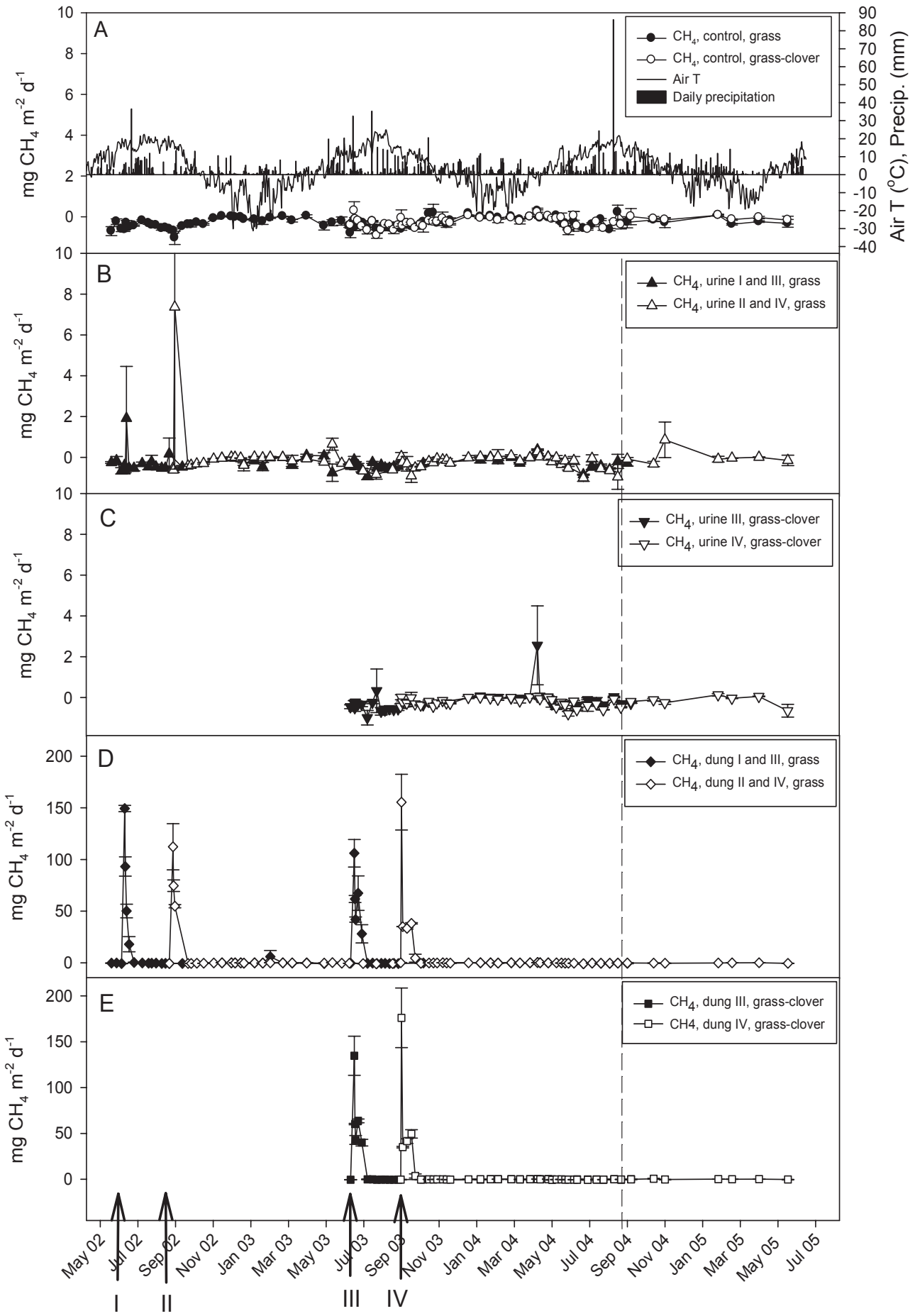

Fig. 1A-E. A) Air temperature and daily precipitation at the study site and methane flux dynamics in control plots. B. $\mathrm{CH}_{4}$ flux dynamics on grass with urine application. C) $\mathrm{CH}_{4}$ flux dynamics on grass-clover with urine application. D) Methane flux dynamics on grass with dung application. E) Methane flux dynamics on grass-clover with dung application. Dashed vertical line indicates the after-effect year (no new excreta applications) when $\mathrm{CH}_{4}$ fluxes were measured from IV patches. Negative values indicate uptake of $\mathrm{CH}_{4}$. Error bars are standard error of the mean and arrows indicate time of application of urine and dung. Note different scales. 


\section{AGRICULTURAL AND FOOD SCIENCE}

M. Maljanen et al. (2012) 21: 91-99

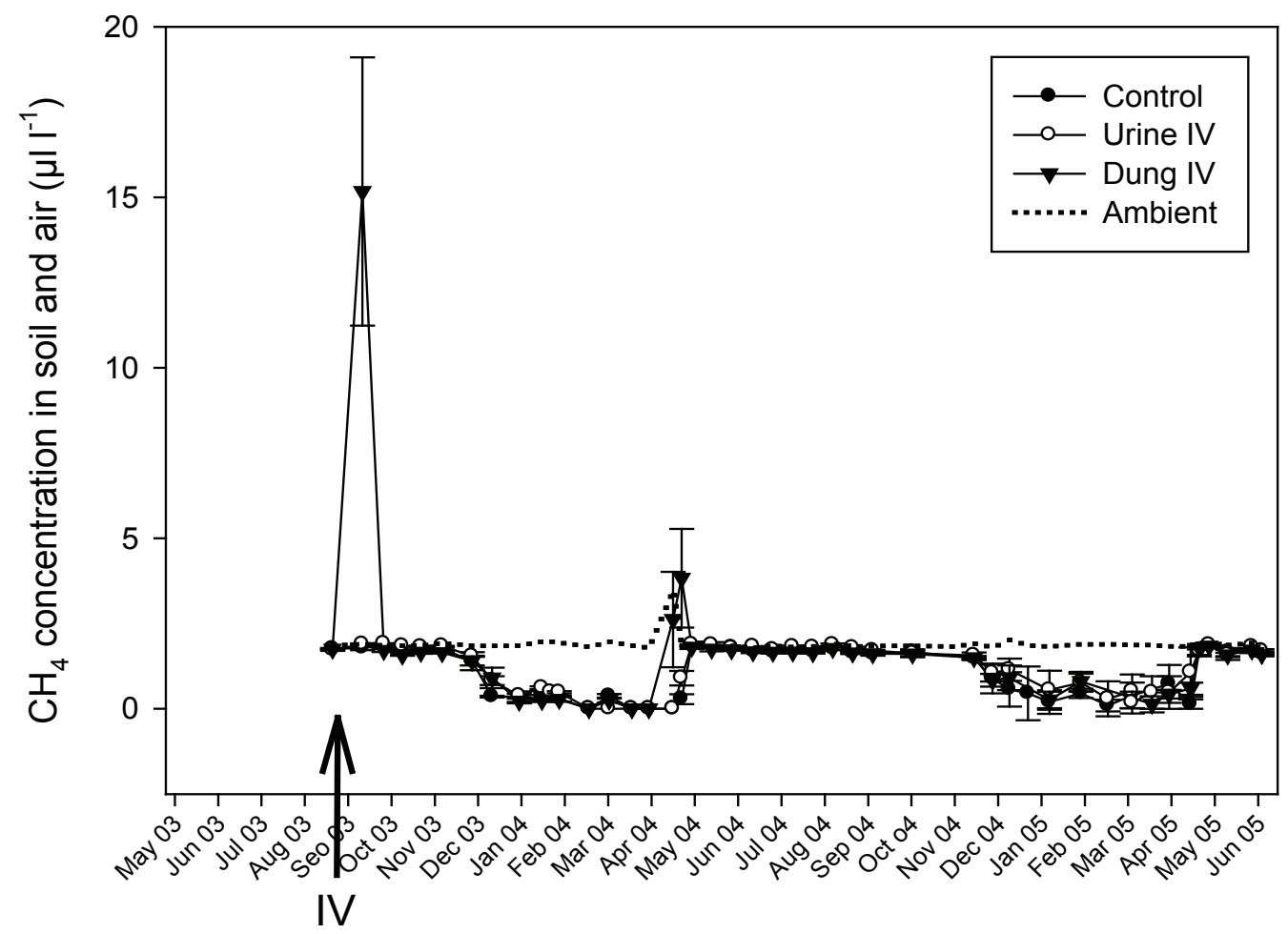

Fig. 2. $\mathrm{CH}_{4}$ concentration in soil with various treatments at the depth of $5 \mathrm{~cm}$ measured from IV patches. Arrow indicates time of application of urine and dung. Dashed line shows the ambient concentration.

The $\mathrm{CH}_{4}$ flux rates measured from each sampling plot were summed over one year after each treatment using time weighted average values to calculate the cumulative annual emission (details in Virkajärvi et al. 2010). The untreated sward acted as a net sink for atmospheric methane, the mean annual uptake rate was $0.60 \pm 0.1 \mathrm{~kg} \mathrm{CH}_{4}$ ha $^{-1}$ (Table 1). There were no significant differences between grass swards and grass-clover swards when the annual fluxes from each plot were compared using analysis of variance (SPSS 17.0). The $\mathrm{N}$-fertilization on grass swards did not change the annual $\mathrm{CH}_{4}$ uptake rate when compared to unfertilized grass-clover swards, however, there were no unfertilized grass sward for comparison. The annual $\mathrm{CH}_{4}$ emission adjusted for typical pasture area was estimated using the coverage percentages of dung (4\%) and urine patches (17\%) and the area without excreta (79\%) (Saarijärvi et al. 2006) with the normal stocking rate 4.0 cows ha ${ }^{-1}$ and grazing season 110 days. When the effect of urine and dung were added (emissions from dung and urine patches multiplied with the coverage) the annual emissions for the grass swards varied from -0.02 to $0.64 \mathrm{~kg} \mathrm{CH}_{4} \mathrm{~m}^{-2}$ and for grass-clover swards from 0.46 to $0.76 \mathrm{~kg}$ $\mathrm{CH}_{4} \mathrm{~m}^{-2}$ showing average net emissions in both cases (Table 1). Thus, the increase in $\mathrm{CH}_{4}$ load by the dairy cow excreta was from 0.71 to $1.33 \mathrm{~kg} \mathrm{ha}^{-1} \mathrm{yr}^{-1}$. 


\section{AGRICULTURAL AND FOOD SCIENCE}

M. Maljanen et al. (2012) 21: 91-99

Table 1. Annual fluxes of $\mathrm{CH}_{4}$ (mean \pm standard deviation) from "Control" $\left(\mathrm{CH}_{4}\right.$ fluxes calculated for a sward without animal excreta) and "Pasture" (including emissions from urine + dung) in addition with $\mathrm{N}_{2} \mathrm{O}$ emissions from "Pasture" (Virkajärvi et al., 2010) calculated also using GWP approach as $\mathrm{CO}_{2}$ equivalents using factor 25 for $\mathrm{CH}_{4}$ and 298 for $\mathrm{N}_{2} \mathrm{O}$ (Solomon et al., 2007). The first and second excreta patches (urine and dung) were applied in June and August 2002 on grass sward (Grass I and Grass II). The third and fourth patches were applied in June and August 2003 on grass and grassclover sward (Grass III and IV; Grass-Clover III and IV). After effect year is a year following application of IV patches (no new excreta applications) and gas fluxes were measured only from those patches. Negative flux values indicate net uptake of $\mathrm{CH}_{4}$ by the ecosystem and positive flux values net emission.

\begin{tabular}{|c|c|c|c|c|c|c|}
\hline $\begin{array}{l}\text { Site and } \\
\text { treatment }\end{array}$ & $\begin{array}{l}\mathrm{CH}_{4} \\
\text { Control } \\
\mathrm{kg} \mathrm{ha}^{-1}\end{array}$ & $\begin{array}{l}\mathrm{CH}_{4} \\
\text { Pasture } \\
\mathrm{kg} \mathrm{ha}^{-1}\end{array}$ & $\begin{array}{l}\mathrm{CH}_{4} \\
\text { Pasture } \\
\mathrm{CO} 2 \text { eq g m}{ }^{-2}\end{array}$ & $\begin{array}{l}\mathrm{N}_{2} \mathrm{O}^{1)} \\
\text { Pasture } \\
\mathrm{kg} \mathrm{N} \mathrm{ha}^{-1}\end{array}$ & $\begin{array}{l}\mathrm{N}_{2} \mathrm{O}^{1)} \\
\text { Pasture } \\
\mathrm{CO} 2 \text { eq } \mathrm{g} \mathrm{m}^{-2}\end{array}$ & $\begin{array}{l}\mathrm{SUM}\left(\mathrm{CH}_{4}+\mathrm{N}_{2} \mathrm{O}\right) \\
\text { Pasture } \\
\mathrm{CO} 2 \text { eq } \mathrm{g} \mathrm{m}^{-2}\end{array}$ \\
\hline Grass, I & $-0.73 \pm 0.16$ & $-0.02 \pm 0.32$ & -0.50 & 4.14 & 193.9 & 193.4 \\
\hline Grass, II & $-0.74 \pm 0.14$ & $0.56 \pm 0.44$ & 14.0 & 3.25 & 152.2 & 166.2 \\
\hline Grass, III & $-0.54 \pm 0.04$ & $0.40 \pm 0.22$ & 10.0 & 3.89 & 182.2 & 192.2 \\
\hline Grass, IV & $-0.44 \pm 0.07$ & $0.64 \pm 0.08$ & 16.0 & 4.00 & 187.3 & 203.3 \\
\hline Grass-clover, III & $-0.65 \pm 0.10$ & $0.46 \pm 0.17$ & 11.5 & 6.38 & 298.8 & 310.3 \\
\hline Grass-clover, IV & $-0.57 \pm 0.10$ & $0.76 \pm 0.12$ & 19.0 & 7.64 & 357.8 & 376.8 \\
\hline \multicolumn{7}{|l|}{ After effect year: } \\
\hline Grass, IV & $-0.69 \pm 0.25$ & $-0.61 \pm 0.28$ & -15.3 & 3.84 & 179.8 & 164.6 \\
\hline Grass-clover, IV & $-0.43 \pm 0.16$ & $-0.43 \pm 0.10$ & -10.8 & 2.22 & 104.0 & 93.22 \\
\hline
\end{tabular}

1) data from Virkajärvi et al. (2010)

\section{Discussion}

The control soils ( $\mathrm{N}$-fertilized grass or unfertilized grass-clover swards) were weak sinks of atmospheric $\mathrm{CH}_{4}$ which was expected since the soils were well aerated and water table remained constantly at a low level. The annual net $\mathrm{CH}_{4}$ uptake rates of the grass and grass-clover control plots $\left(0.44-0.74 \mathrm{~kg} \mathrm{CH}_{4} \mathrm{ha}^{-1}\right.$ ) were similar as reported for $\mathrm{N}$-fertilized grass swards on sandy soils in Finland, $0.51-0.90 \mathrm{~kg} \mathrm{CH}_{4} \mathrm{ha}^{-1}$ (Syväsalo et al. 2006, Regina et al. 2007) and in the range reported from several ecosystems in the Northern Europe (Smith et al. 2000). $\mathrm{CH}_{4}$ uptake rate was dependent on soil temperature and moisture as reported by Syväsalo et al. (2006) and Karhu et al. (2011). There was no difference in the mean $\mathrm{CH}_{4}$ uptake rates between $\mathrm{N}$-fertilized sward (grass, fertilized with $220 \mathrm{~kg} \mathrm{ha}^{-1} \mathrm{~N}$ as $\mathrm{NH}_{4} \mathrm{NO}_{3}$ ) and unfertilized (grass-clover) sward. Hütsch et al. (1994) has reported that high amount of $\mathrm{NH}_{4}{ }^{+}$can inhibit $\mathrm{CH}_{4}$ oxidation, but the amount of $\mathrm{NH}_{4}$ fertilizer in our study did not affect $\mathrm{CH}_{4}$ oxidation. However, the $\mathrm{CH}_{4}$ uptake in the field was lower than the uptake rates measured from upland forest soils in Finland (e.g. Saari et al. 1998, 2004) which was expected since the swards were ploughed regularly, which can reduce $\mathrm{CH}_{4}$ oxidation (Ussiri et al. 2009). 


\section{AGRICULTURAL AND FOOD SCIENCE}

M. Maljanen et al. (2012) 21: 91-99

When emissions from the simulated excreta patches were taken into account the swards turned into net sources of $\mathrm{CH}_{4}\left(0.47 \pm 0.3 \mathrm{~kg} \mathrm{CH}_{4} \mathrm{ha}^{-1} \mathrm{yr}^{-1}\right)$ and the emissions mostly originated from the dung treated plots as previously reported by Jarvis et al. (1995) and Yamulki et al. (1999). The methane emitted after dung application mostly originated from the dung containing methane produced in the enteric fermentation by ruminants or it was produced in the dung patches when applied on soil. This is supported by the bucket experiment where high amounts of $\mathrm{CH}_{4}$ were emitted from the dung. The $\mathrm{C}$ content of dung from dairy cows using similar dietary, $430 \mathrm{~g} \mathrm{C} \mathrm{kg}^{-1}$ ( $\mathrm{P}$. Virkajärvi, unpublished results) is also much higher than C content in urine reported in the literature, 2-6 g C kg-1 (Blaxter et al. 1966, Petersen et al. 2004). The high soil concentration after dung application was probably result of $\mathrm{CH}_{4}$ diffused into the soil from dung. Unfortunately, we do not know the ratio of $\mathrm{CH}_{4}$ originating from the fresh dung and $\mathrm{CH}_{4}$ produced in the soil or dung. Because the soil was well aerated probably it does not have very active methanogenic microbes. Jarvis et al. (1995) reported that soil type (well drained - poorly drained) does not affect emissions from dung patches and $\mathrm{CH}_{4}$ emissions originate mainly from the dung. The maximum emission rates in our study from the dung, $>200 \mathrm{mg} \mathrm{CH}_{4} \mathrm{~m}^{-2} \mathrm{~d}^{-1}$, were in the range of those reported from Europe (from about 100 to $1000 \mathrm{mg} \mathrm{CH}_{4} \mathrm{~m}^{-2} \mathrm{~d}^{-1}$ ) (Jarvis et al. 1995, Flessa et al. 1996, Holter, 1997, Yamulki et al. 1999). The short-lived $\mathrm{CH}_{4}$ fluxes measured in the present experiment are also in line with previous studies (Jarvis et al. 1995, Holter 1997, Yamulki et al. 1999, Chadwick et al. 2000). The lower emission from dung patches I and III may result from drier and warmer conditions in the early grazing season when the dung dried rapidly (Holter 1997, Chadwick et al. 2000). In the later grazing season (patches II and IV), when conditions were cooler and wetter, $\mathrm{CH}_{4}$ emissions were slightly higher.

The small emission peaks after urine application originated probably partly from the urine itself, though little $\mathrm{CH}_{4}$ was emitted from urine in the bucket experiment. According to McDonald et al. (1988) $\mathrm{CH}_{4}$ should not be in urine, and therefore it must have been produced in the urine in the bucket without any soil but we do not know in which way. Another reason for $\mathrm{CH}_{4}$ peaks after urine addition on soil could be lowered $\mathrm{CH}_{4}$ oxidation resulting from the increase in soil water content making the soil anaerobic, thereby favouring $\mathrm{CH}_{4}$ production more than its oxidation. Moreover, $\mathrm{CH}_{4}$ oxidation was likely hindered by the ammonium build up following urine application (e.g. Hütsch et al. 1994, Xu and Inubushi 2004).

The results show that the addition of dairy cow excreta can turn boreal grass sward from a net sink to a weak net source of $\mathrm{CH}_{4}$. The $\mathrm{CH}_{4}$ emissions originate mainly from the dung pats, even if they cover only about $4 \%$ of the pasture area. However, the mean cumulative $\mathrm{CH}_{4}$ emission from the pasture soil here $\left(0.47 \pm 0.3 \mathrm{~kg} \mathrm{CH}_{4}\right.$ ha $\left.^{-1} \mathrm{yr}^{-1}\right)$ is insignificant when compared to the direct annual $\mathrm{CH}_{4}$ emission from dairy cows. The animal- derived $\mathrm{CH}_{4}$ emissions were calculated as follows: the gross energy consumption of cows on pasture feeding was based on results of Sairanen et al. (2005). A conversion factor of $6.5 \%$ of gross energy as $\mathrm{CH}_{4}$ was used (Yan et al. 2000) which resulted to an estimate of $\mathrm{CH}_{4}$ production of 160-176 $\mathrm{kg} \mathrm{CH}_{4}$ cow $^{-1} \mathrm{yr}^{-1}$, which is close to the estimate of $183 \mathrm{~kg} \mathrm{CH}_{4} \mathrm{cow}^{-1}$ reported by Rossi et al. (2001). As the normal stocking rate is 4.0 cows ha-1 $^{-1}$ and typical grazing season lasts 110 days at the study site, (Saarijärvi et al. 2006), the direct emission from cows during the grazing season here is $193-212 \mathrm{~kg} \mathrm{CH}_{4}$ ha $^{-1}$. Therefore, the proportion of emissions from excreta patches of a dairy cow on soil are only $0.2 \%$ of the total $\mathrm{CH}_{4}$ emissions originating from cows during the grazing season. However, the soil compaction by grazing animals and the accumulation of urine and dung patches e.g. close to drinking station may enhance $\mathrm{CH}_{4}$ emissions (Sitaula et al. 2000, Radl et al. 2007) but these factors were not included in this experimental design due to practical reasons. Therefore, the $\mathrm{CH}_{4}$ emissions in this study can be underestimated compared to grazed pasture.

Using the GWP approach (Solomon et al. 2007) the annual $\mathrm{CH}_{4}$ emissions from the pasture soil with simu- 


\section{AGRICULTURAL AND FOOD SCIENCE}

M. Maljanen et al. (2012) 21: 91-99

lated dung and urine patches were on average $12 \mathrm{~kg} \mathrm{ha}^{-1}$ as $\mathrm{CO}_{2}$ equivalents. The atmospheric impact of $\mathrm{CH}_{4}$ fluxes were compared to that of nitrous oxide $\left(\mathrm{N}_{2} \mathrm{O}\right)$ emitted from the same experiment (Virkajärvi et al. 2010). The $\mathrm{CH}_{4}$ emissions from the pasture ecosystem were only an average about $5 \%$ of $\left(\mathrm{N}_{2} \mathrm{O}+\right.$ $\mathrm{CH}_{4}$ ) emissions as $\mathrm{CO}_{2}$ equivalents (Table 1). Results from the after effect year showed that dung does not significantly emit $\mathrm{CH}_{4}$ one year after application and the ability of soil to oxidize $\mathrm{CH}_{4}$ can recover if the site is not used for grazing.

\section{Conclusion}

The boreal grass or grass-clover swards without grazing acted as weak sinks for atmospheric methane. Methane originating mainly from dung patches of grazing animals (4 dairy cows ha ${ }^{-1}$, grazing season 110 d) did turn the soil as a weak source of $\mathrm{CH}_{4}$. However, this emission from pasture soil with dung was only $0.2 \%$ of the total $\mathrm{CH}_{4}$ emission from a dairy cow.

\section{Acknowledgements}

The study was funded by the Maj and Tor Nessling foundation and MTT Agrifood Research Finland. Kirsi Saarijärvi, Pekka Issakainen, Jaana Haapala, Heikki Riisiö, Mari Kaislasuo, Maarit Lauronen, Mika Martikkala and Sari Vauhkala are thanked for their assistance in the field and in the laboratory.

\section{References}

Blaxter, K.L, Clapperton, J.L. \& Martin, A.K. 1966. The heat of combustion of urine of sheep and cattle in relation to its chemical composition and diet. British Journal of Nutrition 20: 449-460.

Chadwick, D.R., Pain, F.B. \& Brookman, S.K.E. 2000. Nitrous oxide and methane emissions following application of animal manure to grassland. Journal of Environmental Quality 29: 277-287.

Flessa, H., Dörsch, P., Beese, F., König, H. \& Bouwman, A.F. 1996. Influence of cattle wastes in nitrous oxide and methane fluxes in pasture land. Journal of Environmental Quality 25: 1366-1370.

Holter, P. 1997. Methane emissions from Danish cattle dung pats in the field. Soil Biology and Biochemistry 29: 31-37.

Hütsch, B.W., Webster, C.P. \& Powlson, D.S. 1994. Methane oxidation in soil as affected by land use, soil pH and N fertilization. Soil Biology and Biochemistry 26: 1613-1622.

Hütsch, B.W. 2001. Methane oxidation in non-flooded soils as affected by crop production - invited paper. European Journal of Agronomy 14: 237-260.

Jarvis, S.C., Lovell, R.D. \& Panayides, R. 1995. Patterns of methane emission from excreta of grazing animals. Soil Biology and Biochemistry 27: 1581-1588.

Karhu, K., Mattila, T., Bergström, I. \& Regina, K. 2011. Biochar addition to agricultural soil increased $\mathrm{CH}_{4}$ uptake and water holding capacity - Results from a short term pilot field study. Agriculture Ecosystems \& Environment 140: 309-313.

Maljanen, M., Liikanen, A., Silvola, J. \& Martikainen, P.J. 2003. Methane fluxes on agricultural and forested boreal organic soils. Soil Use and Management 19: 73-79.

McDonald, P., Edwards, R.A. \& Greenhalgh, J.F.D. 1988. Animal Nutrition. 4th ed. Longman Group, Hong Kong. 543 p.

Mosier, A., Schimel, D., Valentine, D., Bronson, K., Parton, W. 1991. Methane and nitrous oxide fluxes in native, fertilized and cultivated grasslands. Nature 350: 330-332.

Petersen, S.O., Roslev, P. \& Bol, R. 2004. Dynamics of a Pasture Soil Microbial Community after Deposition of Cattle Urine Amended with $\left[{ }^{13} \mathrm{C}\right]$ Urea. Applied Environmental Microbiology 70: 6363-6369. 


\section{AGRICULTURAL AND FOOD SCIENCE}

M. Maljanen et al. (2012) 21: 91-99

Radl, V., Gattinger, A., Chroňákova, A., Němcová, A., Čuhel, J., Simek, M., Munch, J.C., Schloter, M. \& Elhottova, D. 2007. Effects of cattle husbandary on abundance and activity of methanogenic archaea in upland soils. The ISME Journal 1: 443-452.

Regina, K., Pihlatie, M., Esala, M. \& Alakukku, L. 2007. Methane fluxes from boreal arable soils. Agriculture Ecosystems \& Environment 119: 346-352.

Rossi, F., Vecchia, P. \& Masoero, F. 2001. Estimate of methane production from rumen fermentation. Nutrient Cycling in Agroecosystems 60: 89-92.

Saari, A., Heiskanen, J. \& Martikainen, P.J. 1998. Effect of the organic horizon on methane oxidation and uptake in soil of a boreal Scots pine forest. FEMS Microbiology Ecology 26: 245-255.

Saari, A., Smolander, A. \& Martikainen, P.J. 2004. Methane consumption in a frequently nitrogen-fertilized and limed spruce forest soil after clear-cutting. Soil Use and Management 20:65-73.

Sairanen, A., Khalili, H., Nousiainen, J., Ahvenjärvi, S. \& Huhtanen, P. 2005. The effect of concentrate supplementation on nutrient flow to the omasum in dairy cows receiving freshly cut grass. Journal of Dairy Science 88: 1443-1453.

Saarijärvi, K., Mattila, P.K. \& Virkajärvi, P. 2006. Ammonia volatilization from artificial dung and urine patches measured by the equilibrium concentration technique (JTI method). Atmospheric Environment 40: 5137-5145.

Saarijärvi, K., Virkajärvi, P. \& Heinonen-Tanski, H. 2007. Nitrogen leaching and herbage production on intensively managed grass and grass-clover pastures on sandy soil in Finland. European Journal of Soil Science 58: 1382-1392.

Sitaula, B.K., Hansen, S., Sitaula, J.I.B. \& Bakken, L.R. 2000. Methane oxidation potentials and fluxes in agricultural soil: Effects of fertilisation and soil compaction. Biogeochemistry 48: 323-339.

Smith, K.A., Dobbie, K.E, Ball, B.C., Bakken, L.R., Sitaula, B.K., Hansen, S., Brumme, R., Borken, W, Christensen, S, Priemé, A., Fowler, D., MacDonald, J.A., Skiba, U., Klemedtsson, L, Kasimir-Klemedtsson, Å, Degorska A. \& Orlanski, P. 2000. Oxidation of atmospheric methane in Northern European soils, comparison with other ecosystems, and uncertainties in the global terrestrial sink. Global Change Biology 6: 791-803.

Solomon, S., Qin, D., Manning, M., Alley, R.B., Berntsen, T., Bindoff, N.L., Chen, A., Chisthaisong, A., Gregory, J.M., Hegerl, G.C., Heimann, M., Hewitson, B., Hoskins, B.J., Foos, F., Jouel, J., Kattsov, V., Lohmann, U., Maysuno, T., Molina, M., Nicholls, N., Overpack, J., Raga, G., Ramaswamy, V., Ren, J., Rusticucci, M., Sommerville, R., Stocker, T.F., Whetton, P., Wood, R.A. \& Wratt, D. 2007. Technical summary. In: Climate Change 2007: The physical Science Basis. Contribution of Working Group I to the fourth Assessment Report of the Intergovernmental Panel on Climate Change.

Sommerfeld, R.A., Mosier, A.R. \& Musselman, R.C. 1993. $\mathrm{CO}_{2}, \mathrm{CH}_{4}$ and $\mathrm{N}_{2} \mathrm{O}$ flux through a Wyoming snowpack and implications for global budgets. Nature 361: 140-142.

Syväsalo, E., Regina, K., Turtola, E., Lemola, R. \& Esala, M. 2006. Fluxes of nitrous oxide and methane, and nitrogen leaching from organically and conventionally cultivated sandy soil in western Finland. Agriculture Ecosystems \& Environment 113: 342-348.

Ussiri, D.A.N., Lal, R. \& Jarecki, M. K. 2009. Nitrous oxide and methane emission from long-term tillage under a continuous corn cropping system in Ohio. Soil \& Tillage Research 104: 247-255.

Virkajärvi, P., Maljanen, M., Saarijärvi, K., Haapala, J. \& Martikainen, P.J. 2010. $\mathrm{N}_{2} \mathrm{O}$ emissions from boreal grass and clover grass pasture soils. Agriculture Ecosystems \& Environment 137: 59-67.

$\mathrm{Xu}, \mathrm{X}$. \& Inubushi, K. 2004. Effects of $\mathrm{N}$ sources and methane concentrations on methane uptake potential of a typical coniferous forest and its adjacent orchard soil. Biology and Fertility of Soils 40: 215-221.

Yamulki, S., Jarvis, S.C. \& Owen, P. 1999. Methane emission and uptake from soils as influenced by excreta deposition from grazing animals. Journal of Environmental Quality 28: 676-682.

Yan, T., Agnew, R.E., Gordon, F.J. \& Porter, M.G. 2000. Prediction of methane energy output in dairy and beef cattle offered grass silage based diets. Livestock Production Science 64: 253-263. 